\title{
COMPUTATIONAL TOOL FOR SELECTION AND RANKING OF PULL-TYPE FORAGE HARVESTERS
}

Daniel Duarte da Silveira ${ }^{1}$ (D), Marlon Soares Sigales ${ }^{2}$ (D), Ramón Justiniano Benítez Centurion² (D), Ângelo Vieira dos Reis ${ }^{2}$ \& Mauro Fernando Ferreira ${ }^{2}$ iD

1 - Federal University of Pelotas, Faculty of Agronomy Eliseu Maciel, Animal Science Department, Pelotas, Rio Grande do Sul, Brazil

2 - Federal University of Pelotas, Faculty of Agronomy Eliseu Maciel, Rural Engineering Department, Pelotas, Rio Grande do Sul, Brazil

\section{Keywords:}

Agricultural machinery

Algorithm

Forage harvest

Comparison

Ranking

Selection

\section{ABSTRACT}

The variety of forage harvester models available in the Brazilian market demands practical tools for selecting and ranking this equipment. The present study aimed to develop an algorithm capable of providing simple and objective criteria that assist in decision-making for purchase. The communication channel of the companies was used to obtain technical specifications and the price of the equipment, which were tabulated in spreadsheets. The instructions for the manipulation of the obtained data were elaborated in the software $\mathrm{R}$, with calculated ranks for the following requirements based on simulated information about a farm: price (PR), productivity and price relation (PROD.PR), fuel consumption (FC), operational comfort (OC), versatility (VERS), and overall (ALL). We obtained information from 45 models belonging to eight companies. The best machine in the overall rank (Cremasco Custom 950 C-III) was similar in the PR, PROD.PR, and FC ranks and the worst rank for OC. The algorithm established allowed the selection and ranking of the analyzed forage harvesters, providing simple, objective, and easily interpreted criteria for farmers' use and the technicians who assist them.

\section{Palavras-chave:}

Algoritmo

Colheita de forragem

Comparação

Máquinas agrícolas

Mecanização agrícola

Produtividade

Ergonomia

\section{FERRAMENTA COMPUTACIONAL PARA SELEÇÃO E RANQUEAMENTO DE COLHEDORAS DE FORRAGEM DE ACIONAMENTO TRATORIZADO \\ RESUMO}

A variedade de modelos de colhedoras de forragem disponíveis no mercado demanda ferramentas práticas para selecionar e ranquear esses equipamentos. $\mathrm{O}$ presente estudo visou à elaboração de um conjunto de instruções capaz de fornecer critérios simples e objetivos que auxiliem na tomada de decisão para aquisição. Foram utilizados os canais de comunicação das empresas fabricantes para a obtenção das especificações técnicas e cotações dos equipamentos, as quais foram tabuladas em planilhas eletrônicas. As instruções para a manipulação dos dados obtidos foram elaboradas no software $\mathrm{R}$, sendo calculados ranques para os seguintes quesitos seguindo informações simuladas a respeito de uma propriedade rural: cotação (PR), razão entre produtividade e cotação (PROD.PR), consumo de combustível (FC), conforto de operação (OC), versatilidade (VERS) e geral (ALL). Foram obtidas informações de 45 modelos pertencentes a 8 marcas. A melhor máquina no ranque geral (Cremasco Custom $950 \mathrm{C}$-III) obteve colocação similar nos ranques PR, PROD.PR e FC e pior colocação para OC. O algoritmo construído permitiu a seleção e o ranqueamento das colhedoras de forragem analisadas, fornecendo critérios simples, objetivos e de fácil interpretação para o uso dos produtores e dos técnicos que os assistem. 


\section{INTRODUCTION}

In livestock systems, cost mostly centers on animal feeding, which accounts for at least $60 \%$ of the total cost (BECKER, 2008). Further, Brazil is recognized by extensive livestock, in which cattle are reared and maintained in pastures, either native or cultivated, important niches, such as the dairy sector, demand for conserved fodder, whether to overcome seasonal food shortages or the composition of confined animals' diet. In this case, given that the quality of the silage process partially affects the financial returns on the activity, the proper selection of machines for harvesting and processing of fodder is of utmost importance.

In a comprehensive study on the dynamics of ensilage processes in Brazil, Bernardes and Rêgo (2014) showed an important obstacle related to the equipment. In the diagnosis made by these authors, the lack of equipment for harvesting forage in farms is quite common, and the dependence on outsourcing (cooperatives, municipal agricultural patrols, etc.) sometimes results in inappropriate processes of harvest, processing, and ensilage of fodder, significantly affecting the nutritional quality of conserved food. Consequently, it is plausible that more organized production systems, from management and financial perspectives, are concerned with buying their own equipment to improve the results of the ensilage process, resulting in greater production efficiency of livestock.

Currently, there is a wide variety of equipment for harvesting and processing fodder in the national market. Similarly, assuming there is sufficient information regarding technical specifications, operation, and maintenance of the machines, the rancher faces the scarcity of simple criteria and objectives that can rank the products and assist them in decision-making. Although several researchers have been developing machine selection indexes and criteria (FRANCETTO et al., 2013; CASSALHO et al., 2014; ANDERSON et al., 2015a,b), the use of this information, based on software applications, is still limited. Therefore, the present work aimed to develop an algorithm capable of filtering the available equipment database, excluding those considered inadequate and ranking the machinery from an index that summarizes its technical parameters. Consequently, it was necessary to research the technical specifications of the machines available in the Brazilian market to consolidate the database.

\section{MATERIAL AND METHODS}

We obtained information from pull-type machines available in the Brazilian market through contact with equipment manufacturers, conducted using telephone and/or internet channels to simulate a real service provided to a rancher interested in purchasing the products. In the survey, the following information was obtained: company and model of the equipment, culture for which it was developed, harvesting mode, number of knives, number of rotors, number of collecting rollers, rotation required in power take-off (PTO), productivity in tons of processed material per hour $\left(\mathrm{t} \mathrm{h}^{-1}\right)$, minimum and maximum power required in PTO in kilowatts $(\mathrm{kW})$, equipment mass $(\mathrm{kg})$, presence of a system for grain breakage (crackers), particle size $(\mathrm{mm})$, available setup, type of transmission and control, knife profile, sharpening system, tractor coupling mode, and price (US\$). From the information obtained, the database was consolidated, and the statistical description of the variables was performed, in addition to the study of their relations.

Based on the assumption of offering a practical and easy-to-use tool, the following set of information to be collected was delineated and simulated. The R Core Team (R Core Team, 2019) software was used to construct the algorithm and the initial set of instructions aimed at censoring the data to obtain a structure containing only the equipment with the minimum requirements necessary for coupling to the tractor on the farm and, in addition, being appropriate to the culture 
and the product to be processed. The flow of information on the algorithm is shown in Figure 1 .

In the case of the compatibility between the tractor PTO power and equipment power demand, we adjusted the rated engine power of the tractor based on the standard D497.4 (ASAE STANDARDS, 2000). This standard indicates that up to $83 \%$ of gross engine power can be offered by the PTO. Moreover, to match the necessary PTO speed, a routine was included to compare the standard rotation present in the tractor and that required by the machine based on the manufacturer. To segregate machines suitable for the crop and the product to be processed, the equipment was coded into two groups: multicultural (machines capable of harvesting corn (Zea mays), sorghum (Sorghum bicolor), sugarcane (Saccharum officinarum), elephant grass (Pennisetum purpureum), and grass (machines suitable for harvesting small forages). Further, the cultivation method was evaluated to maintain machines that harvest in rows or a total area for in row and broadcast seeding, respectively. The presence of grains in the harvested product was also used as a criterion to maintain machines that had some device for grain breakage (cracker).

After obtaining the list of harvesters considered appropriate to the simulated farm, the next stage comprised the elaboration of indexes for each variable analyzed. The valuation scale of these indexes was given by the reverse ranking concerning the best values. Furthermore, the overall index (ALL) was calculated from the sum of the indexes of each variable analyzed. In this stage, the indexes described in Table 1 were considered.

Rankings were obtained for each index, and the general index, attempting to facilitate interpretation of results.

We performed a simulation to test the algorithm's operation. This simulation assumed a farmer needed to choose a harvester to be used on a Massey Fergusson MF4265 tractor [Rated Engine Power: $47.8 \mathrm{~kW}$; PTO power: $41.3 \mathrm{~kW}$; PTO speed: $540 \mathrm{RPM}$ ] in the corn harvesting for silage. Thus, the possible machines in this situation and their rankings are shown based on the criteria created (Table 1).

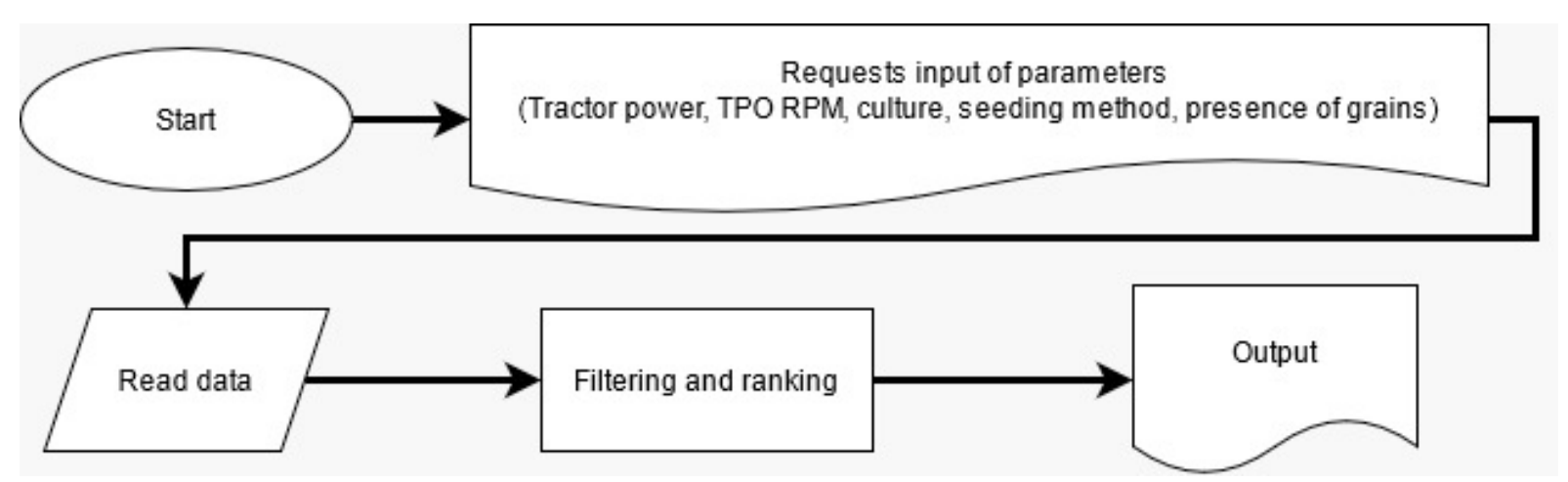

Figure 1. Flow of information on the algorithm

Table 1. Description of analyzed variables

\begin{tabular}{llll}
\hline Variable analyzed & Acronym & Unity & Higher scores when: \\
\hline Price & PR & US\$ & Lower prices \\
Productivity/Price & PROD.PR & $\mathrm{t}^{-1} / \mathrm{US} \$$ & Higher productivity with same \\
Fuel consumption & FC & $\mathrm{L} \mathrm{kW}^{-1} \mathrm{~h}^{-1}$ & Lower consumption estimated \\
Operational comfort & OC & $\mathrm{Score}(1-5)$ & Better comfort technology \\
Versatility & VERS & Score (1-2) & More headers possibilities \\
\hline
\end{tabular}




\section{RESULTS AND DISCUSSION}

There was great resistance from some companies in disseminating the manual of operation and maintenance of their products. In addition, obtaining equipment prices was quite difficult because companies have instructed their sellers to perform a comprehensive data collection of any customer, exposing them to a series of questions about the characteristics of their respective businesses. Such a posture makes it impossible or, at best, makes it difficult for any independent comparison that farmers wished to perform or even the technicians who assisted them. Despite these mishaps, information was obtained from 45 forage harvesters belonging to the following companies: Casale (5), Combine (2), Cremasco (2), JF (11), Jumil (2), Menta (13), Nogueira (6), and Pinheiro (4) and the proportions based on each trait are described in the Figure 2.

It was observed that in the models with 2 lines, the spacing between them varied between 0.45 and $1.50 \mathrm{~m}$, among these, there were models with adjustable spacing. In the total area category, there were measures of maximum working width ranging from 1.00 to $3.20 \mathrm{~m}$, with an average of $1.62 \mathrm{~m}$.

The number of knives were observed in the different models under the study range from 4 to 66 , which were coupled to one $(68.9 \%$ of the models) or two (31.1\% of the models) rotors. The most knife profiles were "C" and " $Z$ " ( $65 \%$ of the models). It is important to highlight that the design of knives is useful for boosting the chopped fodder along the discharge pipe (BOLLER, 2012). In addition, $97.8 \%$ of the machines were equipped with automated edging systems, a relevant feature both in reducing operating costs and the nutritional quality of conserved food (EL SHAL; EL DIDAMONY, 2018). Moreover, concerning the factors that positively affect the nutritional quality of silage, it was noticed that $68.9 \%$ of the harvesters had some type of device for grain breakage. This characteristic is quite important in the silage of crops such as corn, for example, because it provides better use of starch present in grains by rumen microorganisms, generating an increase in the productive potential of animals (FERRARETTO et al., 2018). Another important factor is the theoretical cutting length, which affects the size of the food particles to be conserved. Consequently, the studied models showed a minimum size of 2-7 mm and a maximum size of $10-43 \mathrm{~mm}$, providing an adequate variety of configurations (3-25). This variation can be considered important, given the lengths estimated by manufacturers do not always correspond to the results obtained under field conditions (WEIRICH NETO et al., 2013).

Figure 3 shows that, based on the information provided by the respective manufacturers, at least $90 \%$ of the forage harvesters studied have maximum potential to harvest between 15 and 60 tons of forage per working hour $\left(\mathrm{t} \mathrm{h}^{-1}\right)$. However, it should be noted that almost half of the database machines had maximum capacity to harvest above 15 to $30 \mathrm{t} \mathrm{h}^{-1}$. Although the scientific results of forage harvester tests have a wide range (BOLLER, 2012) it is important to note that tractor-driven harvesters mostly have lower levels of productivity. This feature requires a carefully designed culture planning, mainly in bigger areas. That is, for larger areas it is recommended to scale the planting of the crop, adjusting to the harvest scale resulting from the limitations of the equipment. Thus, it would be possible to obtain a more uniform product, especially in relation to dry matter content, which would result in a forage preserved with lower loss of quality (MUCK, 1988; BOLLER, 2012).

Most machines were developed for threepoint hitch tractors $(82.2 \%)$, and the remaining machines were developed for use on the tractor drawbar. The transmission of power to their moving elements from the cardan axis connected to the PTO showed variation between the models. Some have transmission boxes and additional cardan $(57.8 \%$ of the models), whereas others have reduction coupled directly to the PTO cardan, some reductions were made by gearboxes, whereas others were made with pulleys and belts or chains. Most forage harvesters (91.9\%) required 540 RPM 

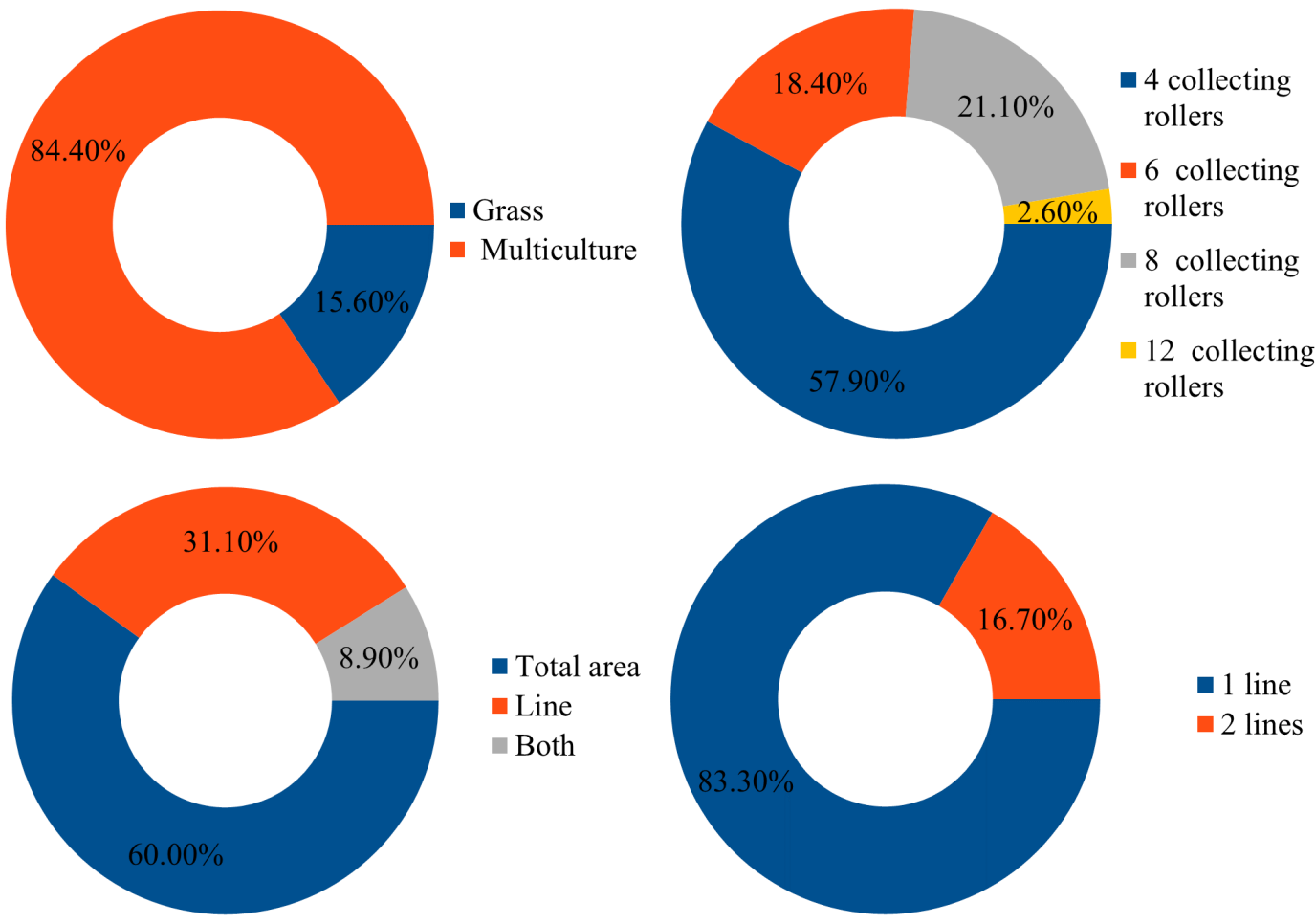

- 1 line

2 lines
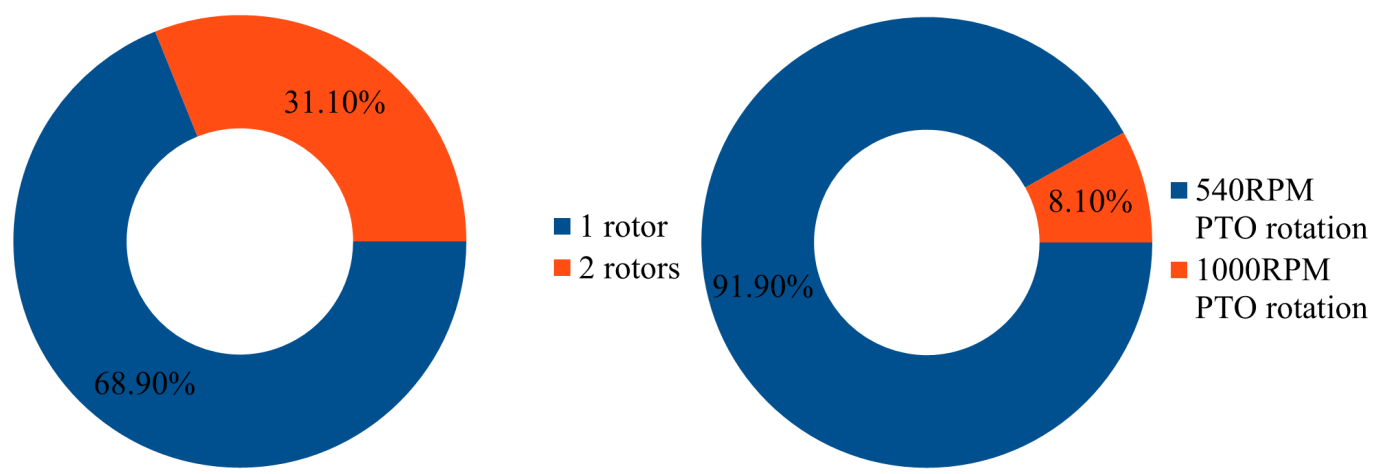

Figure 2. Description of machinery traits

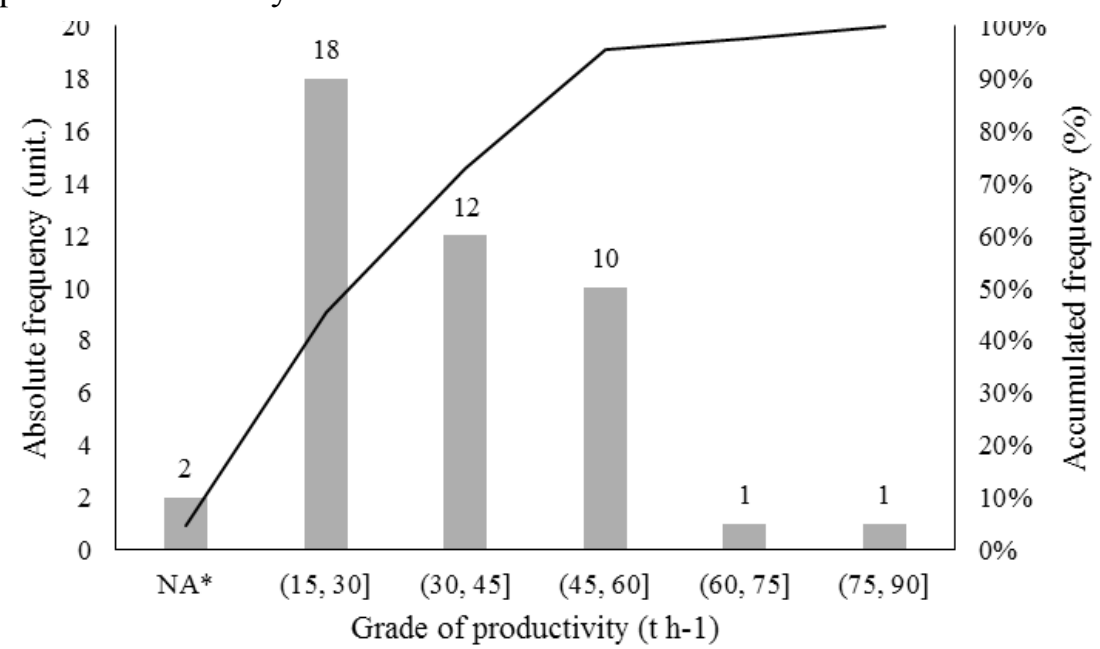

*Information not available

Figure 3. Absolute (bars) and relative (line) frequencies of the forage harvesters based on the maximum productivity measured in tons of fodder processed per working hour 
PTO. Moreover, five models offered the advantage of working at three speeds $(540,600$, and 1000 RPM). Further, the minimum PTO power required by the machines studied ranged from 25.74 to $147.10 \mathrm{~kW}$. At least $70 \%$ of the equipment was grouped in the class up to $90 \mathrm{~kW}$ (Figure 4).

The equipment was priced between US $\$ 5,316.46$ (Custom 950 C-III - Cremasco) and US\$77,508.86 (JF 3,200 AT - JF), and it is necessary to emphasize that in the research stage dedicated to data collection, many dealers, without apparent reason, in addition to hindering access to data, denied providing equipment prices. Hence, prices were obtained for only 15 of the 45 models studied. However, based on the information provided by the companies, it was observed that the maximum estimated productivity level for the machines studied was related to the price of the equipment (Pearson's correlation of 0.975 ). Thus, it was possible to state that, on average, for each additional $\mathrm{t} \mathrm{h}^{-1}$ of productivity, there was an average increase of US\$1,095.20 in the harvester price $(p<0.01$; Figure 5). Similarly, a strong correlation was obtained between the price and mass of the equipment (Pearson's correlation of 0.994), with an estimated increase of US\$19.05 for each additional unit of mass $(\mathrm{kg})$ in the price of the machines $(\mathrm{p}<0.01$; Figure 6$)$.

In the case of the discharge command, the machines studied showed variability. However, it should be noted that at least $73.3 \%$ of the equipment had hydraulic control, denoting a higher operational comfort in field conditions.

In the case of the proposed simulation, in which the machines were coupled to a Massey Fergusson MF4265 tractor for harvesting corn for silage, the ranking of the equipment (Table 2) showed that three equipment lack ranks for PR and PROD.PR, as their prices could not be obtained from the commercial department of the manufacturers. Consequently, the worst places of this equipment in the general ranking may be owing to underestimation related to the lack of information. In addition, it should be noted that in the VERS item, there was no variability among the selected models (Table 2).

For the best machine in the ALL (CUSTOM 950 C-III; Table 2), there was a similarity in the placement of this equipment in the PR, PROD. PR, and FC ranks. Nevertheless, the comfort of operation of this equipment was considered the worst among the machines evaluated. Hence, because objective measurements of operational comfort have attracted great research interest in recent years (NIETIEDT et al., 2012; KABIR et al.,2014; SIMÕES et al., 2016), reveal that these aspects could promote greater income from human labor. Thus, it would be appropriate for new studies to elaborate an overall index that contained

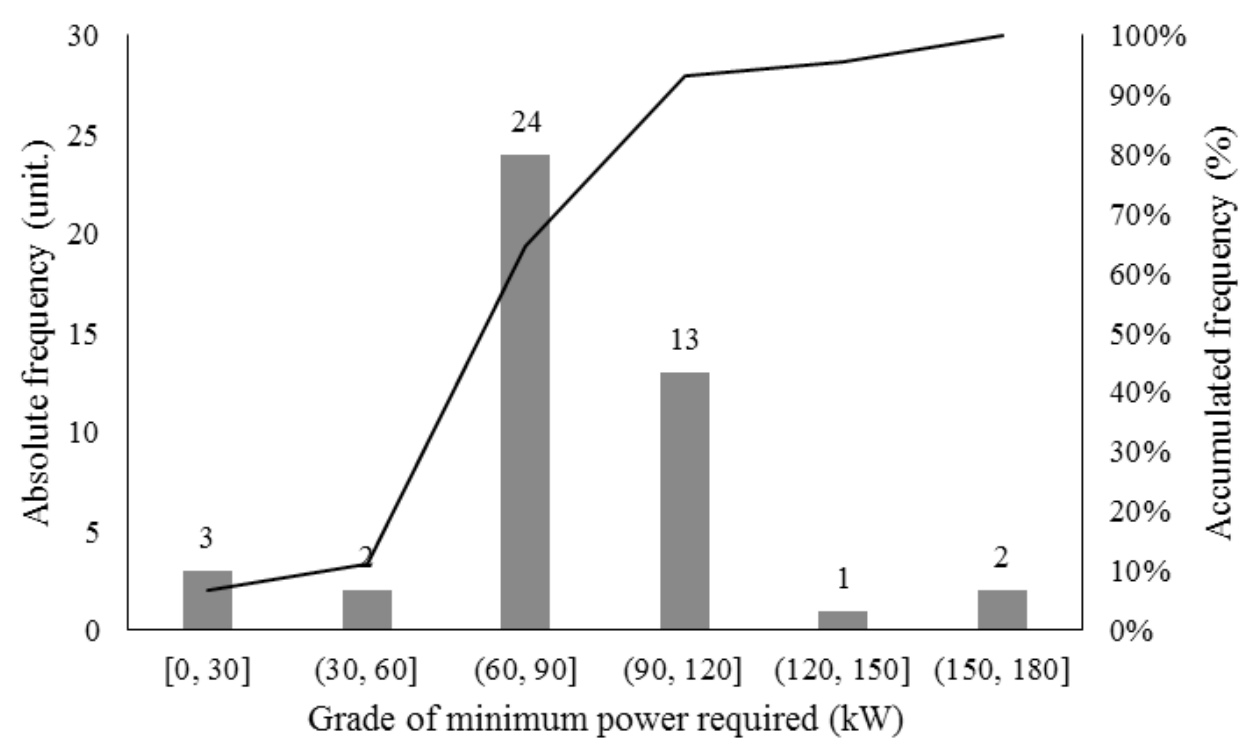

Figure 4. Absolute (bars) and relative (line) frequency of the models of forage harvesters based on the minimum PTO power required 


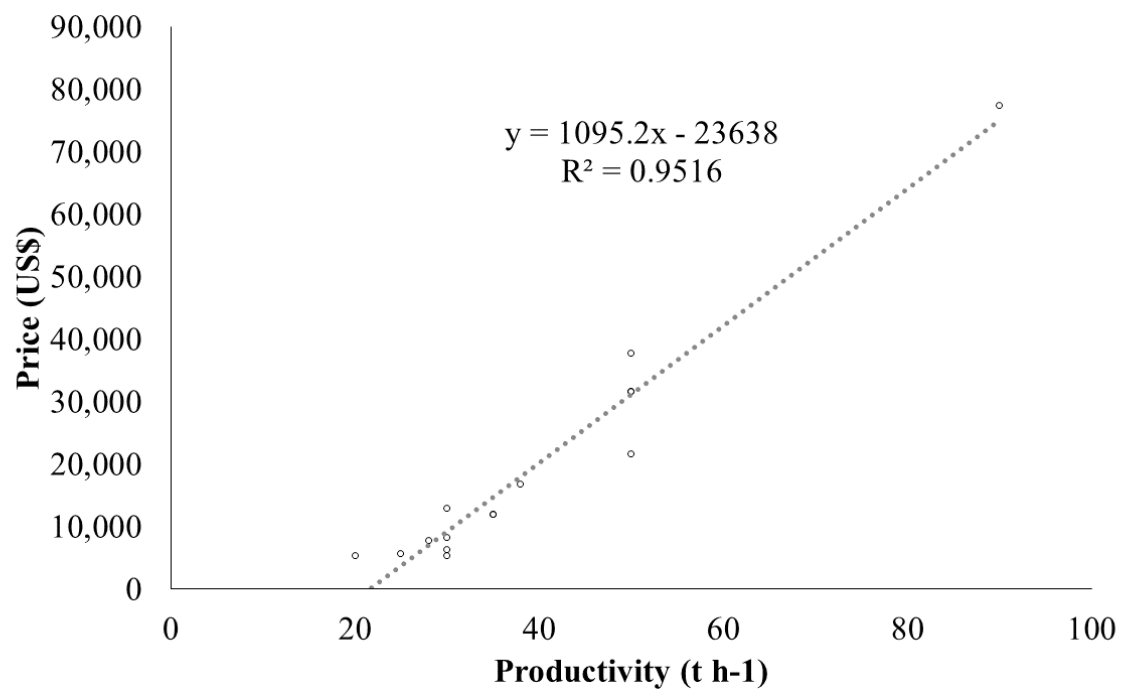

Figure 5. Price in US Dollars* of pull-type forage harvesters based on the maximum productivity $\left(\mathrm{t} \mathrm{h}^{-1}\right)$ estimated by the companies. *Significance level of the curve fit $<0,01$

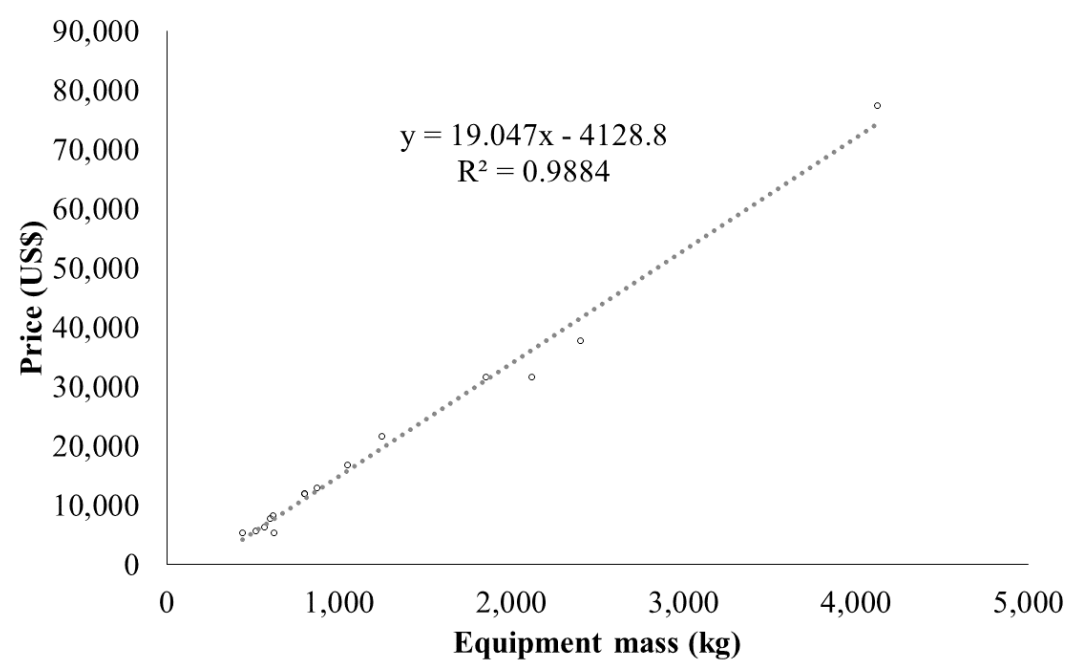

Figure 6. Price in US Dollars* of pull-type forage harvesters based on the equipment mass (kg). *Significance level of the curve fit $<0,01$

Table 2. Forage harvesters ranking based on the simulated information and the indices of price (PR), relation between productivity and price (PROD.PR), fuel consumption (FC), operational comfort $(\mathrm{OC})$, versatility (VERS), and overall index (ALL)

\begin{tabular}{llllccccc}
\hline & \multicolumn{7}{c}{ ITEMS } & \multicolumn{7}{c}{ RANKINGS } \\
\hline COMPANY & MODEL & PR & PROD.PR & FC & OC & VERS & ALL \\
\hline JF & JF C120 S2 (FREE & SPINING & & & & & & \\
& TRANSMISSION BOX) & 3 & 2 & 2 & 2 & 1 & 2 \\
JF & JF C120 S2 (PULLEY AND BELT) & 2 & 3 & 2 & 2 & 1 & 2 \\
CREMASCO & CUSTOM 950 C-III & 1 & 1 & 1 & 3 & 1 & 1 \\
CREMASCO & CUSTOM 930 C-III & - & - & 1 & 3 & 1 & 4 \\
COMBINE & COMBINE - 50 SUPER & - & - & 2 & 1 & 1 & 3 \\
COMBINE & COMBINE - 60 MASTER & - & - & 2 & 1 & 1 & 3 \\
\hline
\end{tabular}

(-) not available. 
weighting factors for the criteria adopted, allowing greater appreciation of the presence of mechanisms associated with the comfort of operation on the equipment. In the case of fuel consumption, there is little variation among the selected models, emphasizing that the machines tied in a rank have the same power requirement in the PTO.

It is important to note that the difficulty in obtaining information on machinery is directly proportional to the contemporary research on criteria for comparing pull-type harvesters, and it is also necessary to develop economic criteria associated with the technical features of the machines. Studies involving a similar approach in the development of comparison systems have not been reported in the literature, making it difficult to compare results. Furthermore, the lack of information may have negatively affected machine rankings.

\section{CONCLUSIONS}

- In this study, an innovation tool was developed by the team to support the decision, which helps in the choice of forage harvesting equipment, where machines are filtered in a database. This database was assembled through extensive research and study of the technical specifications of machines in the Brazilian market, the research materials including technical manuals, company websites, advertisements, and folders from companies willing to supply them. Unfortunately, not all the machines' technical data were found, which makes a complete selection difficult; however, if the tool is widely used and disseminated, it will be a good parameter or even foster the development of technologies and competitiveness, being natural that the companies themselves want their accurate data to be in the selection databases, guaranteeing their positions in the rankings, reaching more sales, in addition to showing confidence in the technical parameters of their products and in the suitability of the data presented.

- It was successfully implemented, where the objectives of filtering the machines, excluding inappropriate machines as per the desired parameters, and presenting hierarchies based on the parameters of PR, PROD.PR, FC, OC, and VERS are fulfilled as seen throughout the work.

- In the future, a smartphone application will be built using this algorithm, with a simple interface such that it can be utilized even by people with minimal technical knowledge, facilitating the selection of forage harvesters by family farmers who need more precise parameters to support the decision.

\section{AUTHORSHIP CONTRIBUTION STATEMENT}

SILVEIRA, D. D.: Conceptualization, Formal Analysis, Investigation, Methodology, Software, Writing - original draft; SIGALES, M.S.: Conceptualization, Data curation, Investigation, Visualization, Writing - review \& editing; CENTURION, R.J.B.: Conceptualization, Data curation, Investigation, Visualization, Writing review \& editing; REIS, A.V.: Conceptualization, Project administration, Supervision, Validation, Writing - review \& editing; FERREIRA, M.F.: Conceptualization, Project administration, Supervision, Validation, Writing - review \& editing.

\section{DECLARATION OF INTERESTS}

The authors declare that they have no known competing financial interests or personal relationships that could have appeared to influence the work reported in this paper.

\section{ACKNOWLEDGMENT}

This study was financed in part by the Coordenação de Aperfeiçoamento de Pessoal de Nível Superior - Brasil (CAPES) - Finance Code 001. Additionally, the authors would like to thank the Núcleo de Inovação em Máquinas e Equipamentos Agrícolas (NIMeq) of the Federal University of Pelotas (UFPel), Rural Engineering Department, the Programa de Pós-Graduação em Sistemas de Produção Agrícola Familiar, and the Programa de Pós-Graduação em Zootecnia of UFPel. 


\section{REFERENCES}

ASAE - American Society of Agricultural Engineers. ASAE D497.4: agricultural machinery management data. 47 th ed. St. Joseph: ASAE, 2000.

ANDERSON, N.L.M.; MACHADO, A.L.T.; FERREIRA, M.F.; REIS, A.V. Índices de Depreciação, Ergonomia, Segurança, Nível de ruído e Manutenção como Parâmetros de Avaliação em Tratores Agrícolas de quatro rodas. Revista de la Facultad de Agronomía (La Plata), v. 114, p. 95-100, 2015a.

ANDERSON, N.L.M.; MACHADO, A.L.T.; REIS, A.V.; GOMES, M.C.; FERREIRA, M.F. Desenvolvimento da metodologia multicritério como modelo na seleção de tratores de quatro rodas. Revista de la Facultad de Agronomía (La Plata), v. 114, p. 265-270, 2015 b.

BECKER, G.S. Livestock Feed Costs: Concerns and Options. In: CRC Report for Congress. 2008.

BERNARDES, T.F.; RÊGO, A.C. Study on the practices of silage production and utilization on Brazilian dairy farms. Journal of Dairy Science, v.97, p.1852-1861, 2014.

BOLLER, W. Máquinas para a colheita e conservação de forragens. In: FONTANELI, R.S.; SANTOS, H.P.; FONTANELI, R.S. Forrageiras para integração lavoura-pecuária-floresta na região Sul-Brasileira. Brasília: Embrapa, 2012.

CASSALHO, M.; BERNARDY, R.; MASSOCO, D.; BALLESTRA, M.R.G.; FERREIRA, M.F. Seleção de pulverizadores de barra montados através de coeficiente tecnológico. In: X Congresso da Sociedade Brasileira de Sistemas de Produção (SBSP). Foz do Iguaçu, PR. Anais do X Congresso da Sociedade Brasileira de Sistemas e Produção 2014, 2014.

EL SHAL, A.M.; DIDAMONY, M.I. Performance of a maize chopping machine with an attached sharpener unit. Journal of Soil Science and Agriculture Engineering, v.9, n.12, p.793-798, 2018.
FERRARETTO, L.F.; SHAVER, R.D.; LUCK, B.D. Silage review: Recent advances and future technologies for whole-plant and fractionated corn silage harvesting. Journal of Dairy Science, v.101, p.3937-3951, 2018.

FRANCETTO, T.R.; Dagios, R.F.; FERREIRA, M.F.; ALONÇO, A.S. Utilização do índice de adequação de semeadoras-adubadoras de precisão como ferramenta de comparação entre modelos. In: XLII Congresso Brasileiro de Engenharia Agrícola. Fortaleza, CE. Os desafios para o desenvolvimento rural sustentável, 2013

KABIR, S.N.; RYU, M-J.; CHUNG, S-O; KIM, Y-J.; CHOI, C-H.; HONG, S-J.; SUNG, J-H. Research trends for performance, safety, and comfort evaluation of agricultural tractors: a review. Journal of Biosystems Engineering, v.39, n.1, p.21-33, 2014.

MUCK, R.E. Factors influencing silage quality and their implications for management. Journal of Dairy Science, v.71, p.2992-3002, 1988.

NIETIEDT, G.H.; RIBAS, R.L.; SCHLOSSER, J.F.; FRANTZ, U.G.; CASALI, A.L.; UHRY, D. Distribuição dos comandos de operação em tratores agrícolas nacionais com até $55 \mathrm{~kW}$ de potência. Revista Brasileira de Engenharia Agrícola e Ambiental, v.16, n.6, p.690-695, 2012.

R CORE TEAM. R: A language and environment for statistical computing. $\mathrm{R}$ Foundation for Statistical Computing, Vienna, Austria. 2019. Available at: https://www.R-project.org/. Access in: 3 dec. 2019.

SIMÕES, D.; SANTIN, L.G.; FENNER, P.T. Ergonomic characterization of three sugar cane harvester machinery models. African Journal of Agricultural Research, v.11, n.8, p.724-729, 2016.

WEIRICH NETO, P.H.; GARBUIO, P.W.; SOUZA, N.M.; DELALIBERA, H.C.; LEITÃO, K. Fragment size of corn silage according to the dry matter and forage harvester adjustments. Engenharia Agrícola, v.33, n.4, p.764-771, 2013. 